\title{
PERBARENGAN TINDAK PIDANA PEMBUNUHAN DAN PENCURIAN PERSPEKTIF HUKUM PIDANA ISLAM
}

\author{
Subairi Chasen CV. Sinar Tenggara, \\ \begin{tabular}{l|ll} 
Subairichasen.91@gmail.com Jl. Perlis Utara No.60 Surabaya &
\end{tabular}
}

\begin{abstract}
This article discusses criminal concourse of organized murder and theft with force which is regulated in Penal code article 340 and 55. The subjective and objective aspects in these crime is fulfilled and beyond reasonable doubt. From the perspective of Islamic criminal law, organized murder and theft concourse is called ta'addud al-jarâ'im in which lighter crime (theft) is absorbed by weightier crime (organized murder). The concept absorption is named al-jabb in Islamic criminal law. Thus, the punishment of theft is absorbed by the punishment of organized murder, which is capital punishment (qishâsh).
\end{abstract}

Keywords: Criminal concourse, organized murder, forced theft, Islamic criminal law.

\begin{abstract}
Abstrak: Artikel ini membahas tentang perbarengan tindak pidana antara pembunuhan berencana dan pencurian dengan kekerasan dalam tinjauan fikih jinâyah. Kejahatan perbarengan tindak pidana antara pembunuhan berencana dan pencurian dengan kekerasan melanggar ketentuan pasal 340 KUHP jo. Pasal 55 ayat (1) ke 1 dan pasal 365 ayat (2) ke 2. Dalam pandangan fikih jinâyah, kasus perbarengan tindak pidana (concursus) pembunuhan berencana dan pencurian dengan kekerasan seharusnya mendapat hukuman mati atau qishâsh. Hal tersebut didasarkan kepada salah satu teori yang digunakan dalam memutuskan perkara gabungan tindak pidana yang di dalam kaidah fikih jinâyah dikenal dengan ta'addud al-jarâ'im atau gabungan hukuman, yaitu teori penyerapan (al-jabb). Teori al-jabb atau teori penyerapan adalah penjatuhan satu hukuman terhadap pelaku tindak pidana ganda dengan cara hukuman yang lebih kecil diserap oleh hukuman yang lebih besar, dalam hal ini adalah hukuman mati.
\end{abstract}

Kata Kunci: Perbarengan tindak pidana, pembunuhan berencana, pencurian dengan kekerasan, hukum pidana Islam. 


\section{Pendahuluan}

Manusia merupakan salah satu makhluk Allah yang diberikan kelebihan dari pada makhluk-makhluk lainnya yaitu berupa akal. Oleh karena itu, manusia dituntut untuk dapat melakukan hal-hal yang telah diperintahkan oleh-Nya dan menjauhi segala hal yang dilarang-Nya sebagai wujud syukur atas apa yang telah diberikan-Nya kepada kita. Dalam kehidupan sehari-hari manusia dituntut agar otaknya dapat berfikir dengan jernih sehingga dapat melakukan hal-hal yang dianggap baik dalam sebuah lingkungan masyarakat. Namun, tidak semua manusia memakai akal fikirannya dengan baik dan jernih, sehingga timbullah beberapa macam kejahatan dan pelanggaran dalam kehidupan bermasyarakat seperti pembunuhan, pencurian, penganiayaan dan lain sebagainya.

Pembunuhan adalah menghilangkan nyawa orang lain, baik dengan cara sengaja maupun dengan cara tidak sengaja. Adapun pencurian ialah mengambil harta orang lain dengan cara sembunyi-sembunyi dengan maksud untuk dimiliki sebagian ataupun semuanya dengan cara melawan hukum.

Dalam hukum pidana Indonesia, pembunuhan termasuk klasifikasi kejahatan terhadap nyawa, sedangkan pencurian masuk ke dalam kategori kejahatan terhadap harta. Pembunuhan diatur mulai pasal 338 KUHP sampai pasal $350 \mathrm{KUHP}$, sedangkan pencurian diatur mulai pasal 362 KUHP sampai pasal 367 KUHP. ${ }^{1}$

Di dalam hukum pidana Islam, pembunuhan termasuk jarîmah qishâsh diyat yaitu suatu kejahatan terhadap jiwa (menghilangkan nyawa) dan anggota badan (pelukaan) yang diancam dengan hukuman qishâsh (serupa/semisal) atau hukum diyat (ganti rugi dari si pelaku atau ahlinya kepada si korban atau walinya). ${ }^{2}$

Ada beberapa kategori pembunuhan dalam hukum pidana Islam yaitu;

1. Pembunuhan dengan sengaja;

2. Pembunuhan semi sengaja;

3. Menyebabkan matinya orang lain dengan kesalahan atau kealpaan. ${ }^{3}$

\footnotetext{
${ }^{1}$ Moeljatno, Kitab Undang-undang Hukum Pidana, (Jakarta: Bumi Aksara, 2011), 28.

${ }^{2}$ Makhrus Munajat, Hukum Pidana Islam di Indonesia, (Yogyakarta: Teras, 2009), 165.

${ }^{3}$ lbid., 167.
} 
Hukuman qishâsh didasarkan kepada firman Allah swt dalam surah al-Baqarah ayat 178-179:

Hai orang-orang yang beriman, diwajibkan atas kamu qishâsh berkenaan dengan orang-orang yang dibunuh; orang merdeka dengan orang merdeka, hamba dengan hamba, dan wanita dengan wanita. Maka barangsiapa yang mendapat suatu pema'afan dari saudaranya, hendaklah (yang mema'afkan) mengikuti dengan cara yang baik, dan hendaklah (yang diberi ma'af) membayar (diyat) kepada yang memberi ma'af dengan cara yang baik (pula). Yang demikian itu adalah suatu keringanan dari Tuhan kamu dan suatu rahmat. Barangsiapa yang melampaui batas sesudah itu, maka baginya siksa yang sangat pedih. Dan dalam qishâsh itu ada (jaminan kelangsungan) hidup bagimu, hai orang-orang yang berakal, supaya kamu bertakwa. ${ }^{4}$

Adapun pencurian termasuk jarîmah hudûd sariqah yaitu perbuatan mengambil harta orang lain secara diam-diam dengan maksud untuk memiliki serta tidak adanya paksaan. Al-Qur'an menyatakan bahwa orang yang mencuri dikenakan hukum potong tangan. Hukum potong tangan tersebut sebagai sanksi bagi pelaku jarimah sariqah. Hukuman potong tangan ini didasarkan kepada firman Allah swt dalam al-Qur'an Surah alMaidah ayat 38:

Laki-laki yang mencuri dan perempuan yang mencuri, potonglah tangan keduanya (sebagai) pembalasan bagi apa yang mereka kerjakan dan sebagai siksaan dari Allah. Dan Allah Maha Perkasa lagi Maha Bijaksana. ${ }^{5}$

Dalam suatu kasus, terkadang kedua kejahatan di atas terjadi secara terpisah, namun ada juga bebarapa kasus yang menyajikan perbarengan tindak pidana antara pembunuhan dan pencurian. Bahwa dalam suatu kasus tindak pidana terdapat dua kejahatan sekaligus, sehingga disebut dengan perbarengan tindak pidana. Gabungan (perbarengan) melakukan tindak pidana (concursus) diatur dalam Kitab Undang-undang Hukum Pidana mulai pasal 63 sampai 71 buku I Bab VI. ${ }^{6}$

Adapun yang dimaksud dengan perbarengan melakukan tindak pidana juga sering dipersamakan dengan gabungan melakukan tindak pidana yaitu seseorang yang melakukan satu perbuatan yang melanggar beberapa ketentuan hukum atau melakukan beberapa perbuatan pidana

\footnotetext{
${ }^{4}$ Ahmad Wardi Muslich, Pengantar dan Asas Hukum Pidana Islam, (Jakarta: Sinar Grafika, 2004$), 37$.

${ }^{5}$ Makhrus Munajat, Hukum Pidana Islam di Indonesia, 145.

6 Nasihuddin, "Gabungan Melakukan Tindak Pidana (Concursus) Menurut KUHP", http://www.nasihudin.com/artikel/gabungan-melakukan-tindak-pidana-concursus-menurutkuhp/28/.html, diakses pada tanggal 24 Juni 2014.
} 
yang masing-masing perbuatan itu berdiri sendiri yang akan diadili sekaligus, di mana salah satu dari perbuatan itu belum mendapatkan keputusan tetap. ${ }^{7}$

Perbarengan atau gabungan peristiwa pidana ini dibedakan menjadi tiga macam:

1. Gabungan satu perbuatan (concursus idealis) termuat dalam pasal 63. Concursus idealis adalah apabila pelaku melakukan suatu perbuatan yang dapat terkena oleh bermacam-macam ketentuan, seperti melakukan penganiayaan terhadap seorang petugas yang sedang malaksanakan tugasnya. Dalam hal ini bisa dikatakan telah terjadi penganiayaan dan melawan petugas.

2. Perbuatan yang diteruskan (Voortgezette handeling) dalam pasal 64. Yaitu beberapa perbuatan yang satu dan yang lain ada hubungannya, agar dapat dipandang sebagai suatu perbuatan yang diteruskan.

3. Gabungan beberapa perbuatan (concursus realis) termuat dalam pasal 65. Concursus realis adalah terjadinya beberapa macam kejahatan dari pelaku, sehingga dari masing-masing perbuatan dianggap sebagai tindak pidana yang berdiri sendiri, seperti membunuh dan mencuri. ${ }^{8}$

Dari pasal-pasal tersebut nantinya dapat menghapus kesan yang selama ini ada dalam masyarakat bahwa seseorang yang melakukan gabungan beberapa perbuatan pidana, ia akan mendapatkan hukuman yang berlipat ganda sesuai dengan perbuatan yang dilakukannya. ${ }^{9}$

Berbeda dengan pengulangan yang tidak mengatur mengenai ketentuan umumnya, hal perbarengan dimuat ketentuan umumnya dalam bab VI ( pasal 63-71 ) KUHP. Peraturan mengenai perbarengan pada dasarnya ialah suatu ketentuan mengenai bagaiamana cara menyelesaikan perkara dan menjatuhkan pidana (sistem penjatuhan pidana) dalam hal apabila satu orang telah melakukan lebih dari satu tindak pidana di mana semua tindak pidana itu belum diperiksa dan diputus oleh pengadilan. ${ }^{10}$

\footnotetext{
${ }^{7}$ Aruan Sakidjo dan Bambang Pornomo, Hukum Pidana Dasar Aturan Umum, Hukum Pidana Kodifikasi, (Jakarta: Ghalia Indonesia, 1990), 170.

${ }^{8}$ R. Soesilo, Kitab Undang-undang Hukum Pidana Serta Komentar-komentarnya Pasal Demi Pasal, (Bogor: POLITEIA, 1988), 80.

${ }^{9}$ Adami Chazawi, Pelajaran Hukum Pidana 2, (Jakarta: Rajawali Pers, 2002), 109.

${ }^{10}$ C.S.T, Kansil dan Christine S.T. Kansil. Latihan Ujian Hukum Pidana. (Jakarta: Sinar Grafika, 1994), 267.
} 
Ketentuan perbarengan itu mengatur dan menentukan mengenai cara menyidangkan atau memeriksa (meyelesaikan) perkara dan cara atau sistem penjatuhan pidananya terhadap satu orang pembuat yang telah melakukan tindak pidana lebih dari satu yang semuanya belum diperiksa dan diputuskan oleh pengadilan. Bila semata-mata dilihat dari pandangan bahwa hanya dijatuhkan satu pidana kemudian dapat diperberat, tanpa melihat di sana ada beberapa tindak pidana, maka di sini perbarengan dapat dianggap sebagai pemberatan pidana. Akan tetapi apabila dilihat semata-mata ada beberapa tindak pidana, tetapi hanya dijatuhkan satu pidana saja yakni terhadap aturan pidana yang terberat ancaman pidananya, walaupun dengan dapat ditambah sepertiga yang terberat (seperti pasal 65) maka tampaknya pada perbarengan tidak ada pemberatan pidana. ${ }^{11}$

Dari latar belakang permasalahan yang telah diuraikan di atas, penulis tertarik untuk membahas tentang tinjauan fikih jinâyah terhadap perbarengan tindak pidana antara pembunuhan berencana dan pencurian dengan kekerasan.

\section{Pengertian Perbarengan Tindak Pidana (Concursus)}

Dalam fikih jinâyah (concursus) atau perbarengan tindak pidana disebut dengan istilah ta'addud al-jarầim (gabungan tindak pidana). Adapun perbarengan tindak pidana (concursus) menurut A. Hanafi adalah seseorang yang memperbuat beberapa macam jarîmah di mana masingmasingnya belum mendapatkan putusan akhir. ${ }^{12}$ Menurut Abdul Qadir Audah, gabungan jarîmah dikatakan ada ketika seseorang melakukan beberapa macam jarîmah yang berbeda di mana dari masing-masing perbuatan tersebut belum mendapatkan putusan akhir dari seorang hakim. ${ }^{13}$ Jadi concursus atau perbarengan tindak pidana adalah beberapa macam tindak pidana yang dilakukan oleh seseorang yang mana setiap perbuatan tersebut pelakunya belum mendapatkan vonis.

Perbarengan tindak pidana atau gabungan bagi pelaku jarîmah pada intinya dapat dibagi ke dalam dua sifat:

1. Gabungan anggapan (concursus idealis) yaitu adanya dua gabungan jarîmah itu karena halnya bersifat anggapan, sedangkan pelakunya

\footnotetext{
${ }^{11}$ Teguh Prasetyo, Hukum Pidana, (Jakarta: Rajawali Pers, 2011), 179.

${ }^{12}$ Ahmad Hanafi, Asas-asas Hukum Pidana Islam, (Jakarta: Bulan Bintang, 1990), 326.

${ }^{13}$ Abdul Qadir Awdah, Al-Tasyrî' al-jinâ'iy al-Islâmiy, (Beirut: Dar al-Kitab al-Arabi, t.t), 744.
} 
hanya berbuat jarimah. ${ }^{14}$ Misalnya seseorang melakukan pemukulan terhadap petugas dalam hal ini bisa dikatakan sebagai pemukulan dan melawan petugas.

2. Gabungan nyata (concursus realis) yaitu seseorang melakukan perbuatan jarîmah ganda secara jelas, baik berkenaan dengan jarîmah sejenis maupun berbeda. ${ }^{15}$ Misalnya jarîmah berbeda: si A melakukan penganiayaan terhadap si $\mathrm{B}$, sebelum dijatuhi hukuman juga melakukan pembunuhan terhadap si C. Adapun jarîmah ganda yang sejenis adalah si A mencuri, sebelum dihukum dia melakukan pencurian lagi.

Ada dua hadis yang menjadi dasar hukum atau landasan dasar yang berkaitan dengan perbuatan perbarengan tindak pidana atau gabungan hukuman. Adapun hadisnya sebagai berikut:

1. Hadis yang diriwayatkan oleh Imam Bukhari.

Telah menceritakan kepada kami Musaddad telah menceritakan kepada kami Yahya dari Syu'bah telah menceritakan kepada kami Qatadah dari Anas ra bahwa ada sekelompok orang dari 'Urainah yang sakit terkena udara dingin kota Madinah. Maka Rasulullah saw mengobati mereka dengan memberi bagian dari zakat unta, yang mereka meminum susususunya dan air kencingnya. Namun kemudian orang-orang itu membunuh pengembala unta tersebut dan mencuri unta-untanya sejumlah antara tiga hingga sepuluh. Maka Rasulullah saw mengutus seseorang. Akhirnya mereka dibawa ke hadapan Beliau, lalu kemudian Beliau memotong tangan dan kaki mereka serta mencongkel mata-mata mereka dengan besi panas lalu menjemur mereka di bawah panas dan ditindih dengan bebatuan". Hadis ini dikuatkan juga oleh Abu Qalabah dan Humaid dari Tsabit dari Anas. ${ }^{16}$

2. Hadis yang diriwayatkan oleh Anas bin Malik:

Telah menceritakan kepadaku Malik dari Hisyam ibn 'Urwah dari Bapaknya berkata tentang seorang laki-laki yang menuduh sekelompok orang telah berbuat zina, maka tidaklah hukuman dijatuhkan atasnya melainkan hanyalah satu had saja." Malik berkata; "Walaupun yang tertuduh terpisah-pisah maka tetap dia hanya dikenakan satu hukuman." ${ }^{17}$

\footnotetext{
${ }^{14}$ Makhrus Munajat, Dekonstruksi Hukum Pidana Islam, (Jogjakarta: Logung Pustaka, 2004), 46.

${ }^{15}$ lbid., 47.

${ }^{16}$ Software Kitab 9 Imam Hadith, Kitab Zakat, Bab Memanfaatkan Hewan Sedekah dan Susunya untuk Orang-orang yang Dalam Perjalanan, No. 1405.

${ }^{17}$ Software Kitab 9 Imam Hadith, Kitab Pelanggaran, Bab (Imam Malik) berkata: "Karena itu Pihak yang Tertuduh Merasa Khawatir Jika Permasalahannya Terbongkar Sehingga Diberikan Bukti Kepadanya, No. 1306.
} 


\section{Sistem dan Penerapan Hukum}

Adapun yang menjadi pertimbangan fikih tentang eksistensi concursus atau perbarengan tindak pidana atau gabungan hukuman adalah berdasar pada tiga teori, yaitu:

1. Teori Saling Melengkapi (at-Tadâkhul)

Menurut teori (at-tadâkhul) ketika terjadi gabungan perbuatan atau perbarengan tindak pidana maka hukumannya saling melengkapi atau saling memasuki, sehingga semua perbuatan tersebut hanya dijatuhi satu hukuman seperti halnya orang yang melakukan satu perbuatan jarîmah. Teori tersebut didasarkan atas dua pertimbangan.

a. Meskipun jarîmah yang dilakukan berganda tetapi semuanya itu jenisnya sama. Maka sudah sewajarnya jika pelaku hanya dikenakan satu macam hukuman saja. Contohnya pencurian berulang-ulang.

b. Meskipun perbuatan-perbuatan yang dilakukan berganda berbeda macamnya, namun hukumannya bisa saling melengkapi dan cukup satu hukuman yang di jatuhkan untuk melindungi kepentingan yang sama. Misalnya seseorang yang makan bangkai, darah dan daging babi cukup dijatuhi satu hukuman karena hukuman tersebut dijatuhkan untuk mencapai satu tujuan yaitu melindungi kepentingan seseorang dan juga melindungi kepentingan masyarakat. ${ }^{18}$

Fukaha madzhab Maliki mengatakan bahwa hukuman minumminuman keras dan menuduh zina (qazhaf) adalah saling melengkapi sehingga memakai teori penyerapan, dan oleh karena itu maka hanya dijatuhi satu macam hukuman saja. Alasan mereka ialah bahwa tujuan penjatuhan hukuman pada kedua perbuatan tersebut adalah satu, sebab orang-orang yang minum minuman keras biasanya mengigau, dan siapa yang mengigau maka dia membuat kedustaan. Jadi hukuman minum minuman keras bertujuan mencegah membuat-buat kebohongan.

Fukaha lain berpendapat berbeda bahwa contoh tersebut karena hukuman memfitnah dimaksudkan untuk melindungi kehormatan dan nama baik, sedangkan hukuman minum minuman keras dimaksudkan untuk melindungi sehatnya badan. Jadi kedua hukuman tersebut berbeda tujuannya, dan oleh karena itu maka tidak ada saling melengkapi. ${ }^{19}$

Fukaha Malikiyah yang lain mengatakan bahwa letak saling melengkapi hukum minum minuman keras dengan hukuman memfitnah

\footnotetext{
${ }^{18}$ Ahmad Wardi Muslich, Pengantar dan Asas Hukum Pidana Islam, 168.

${ }^{19}$ Ahmad Hanafi, Asas-asas Hukum Pidana Islam..., 332.
} 
ialah pada persamaan besar hukuman bukan pada persamaan tujuan seperti yang dikatakan oleh fukaha Maliki golongan pertama. Akan tetapi pendapat mereka tidak dapat menimbulkan tanggapan bagi ulama madzhab lain.

Namun jika hukuman-hukuman dari jarîmah yang bermacammacam itu tidak mempunyai kesatuan tujuan seperti contoh jika seseorang melakukan pencurian kemudian melakukan zina, kemudian memfitnah, maka hukuman-hukuman bagi perbuatan-perbuatan tersebut tidak saling melengkapi melainkan dijatuhkan semua. Dengan perkataan lain teori yang dipakai di sini adalah teori berganda biasa. ${ }^{20}$

2. Teori Penyerapan (al-Jabb)

Pengertian penyerapan menurut syariat Islam adalah cukup untuk menjatuhkan satu hukuman saja, sehingga hukuman-hukuman yang lain tidak perlu dijatuhkan. Hukuman dalam konteks ini tidak lain adalah hukuman mati, di mana pelaksanaannya dengan sendirinya menyerap hukuman-hukuman yang lain. ${ }^{21}$

Di kalangan fukaha belum ada kesepakatan tentang penerapan teori penyerapan. Imam Malik, Abu Hanifah dan Ahmad memegang teori terebut, sedangkan Imam Syafi'i tidak memeganginya. Mereka yang memegangi teori ini juga berbeda pendapat tentang sampai di mana daerah berlakunya.

Menurut Imam Malik, apabila hukuman had berkumpul dengan hukuman mati karena Tuhan, seperti hukuman mati karena jarîmah murtad, atau berkumpul dengan hukuman mati karena qishâsh bagi orang lain, maka hukuman had tersebut tidak dapat dijalankan karena diserap oleh hukuman mati tersebut, kecuali hukuman memfitnah saja yang tetap dilaksanakan dengan cara menjilid dahulu delapan puluh kali kemudian dihukum mati.

Menurut Imam Ahmad, apabila terjadi dua jarîmah hudûd seperti mencuri dan berzina bagi orang-orang muhsan, atau minum minuman keras dan mengganggu keamanan (hirâbah) dengan membunuh, maka hanya hukuman mati saja yang dijalankan, sedangkan hukumanhukuman yang lainnya digugurkan. Kalau hukuman hudûd berkumpul dengan hak-hak adami (manusia) di mana salah satunya diancam hukuman mati maka hak-hak adami tersebut harus dilaksanakan terlebih

\footnotetext{
${ }^{20}$ Ibid., 332.

${ }^{21}$ Ahmad Wardi Muslich, Pengantar dan Asas-asas Hukum Pidana Islam..., 169.
} 
dahulu dan hak-hak Tuhan diserap oleh hukuman mati, baik hukuman mati ini sebagai hukuman had atau sebagai hukuman qishâsh. Jadi apabila seseorang memotong jari orang dengan sengaja, kemudian memfitnahnya, di samping mencuri dan berzina serta membunuh orang lain, maka hukumannya ialah dipotong jarinya sebagai hukuman qishâsh, kemudian dijatuhi hukuman had (delapan puluh jild: di sini lebih ditekankan hak adaminya), kemudian lagi dibunuh, sedangkan hukuman-hukuman yang lain gugur. ${ }^{22}$

Bagi Imam Abu Hanifah, pada dasarnya apabila terdapat gabungan hak (hukuman-hukuman) manusia dengan hak Tuhan, maka hak manusialah yang harus didahulukan, karena ia pada umumnya ingin lekas mendapatkan haknya. Jika sesudah pelaksanaan hak manusia tersebut, maka hak Tuhan tidak bisa dijalankan lagi karena hak tersebut terhapus dengan sendirinya. Kalau masih bisa dilaksanakan dan hak-hak Tuhan tersebut lebih dari satu maka satu hak hukuman saja yang dijatuhkan yaitu hukuman yang dapat menggugurkan hukuman-hukuman yang lain. Hal ini sesuai dengan sabda Nabi Muhammad saw:

Telah menceritakan kepada kami Abdurrahman ibn al-Aswad Abu Amr al-Bashri, telah menceritakan kepada kami Muhammad ibn Rabi'ah, telah menceritakan kepada kami Yazid ibn Ziyad ad-Dimasyqi dari Az Zuhri dari 'Urwah dari A' isyah ia berkata; Rasulullah ssaw bersabda: "Hindarilah hukuman had dari kaum muslimin semampu kalian, jika ia mempunyai jalan keluar maka lepaskanlah ia. Karena sesungguhnya seorang imam salah dalam memaafkan lebih baik daripada salah dalam menjatuhi hukuman". (H.R. Imam Tirmizîi). ${ }^{23}$

Bagi Imam Syafi'i tidak ada teori penyerapan (al-jabb) dan semua hukuman harus dijatuhkan selama tidak saling melengkapi (at-tadâkhul). Caranya ialah dengan mendahulukan hukuman-hukuman bagi hak manusia yang bukan hukuman mati, kemudian hukuman bagi hak Tuhan yang bukan hukuman mati dan setelah itu dijatuhi hukuman mati. Misalnya jika seseorang yang bukan muhshan melakukan jarîmah zina, memfitnah (qazhaf), pencurian, gangguan keamanan dengan membunuh, maka urutan penjatuhan hukuman-hukuman tersebut adalah sebagai berikut: hukuman memfitnah dijild sebanyak delapan puluh kali, kemudian ditahan dulu sampai sembuh untuk kemudian dijatuhi hukuman zina yaitu dijilid sebanyak seratus kali, kemudian ditahan lagi

${ }^{22}$ Ahmad Hanafi, Asas-asas Hukum Pidana Islam..., 333.

${ }^{23}$ Abdul Qodir Irfan, Sunan al-Tirmidziy, (Beirut: Dar al-Fikri, 2005), 115. 
sampai sembuh untuk dipotong tangannya karena pencurian yang dilakukannya, dan yang terakhir adalah dijatuhi hukuman mati karena telah melakukan gangguan keamanan dengan membunuh. Jika pelaku tindak pidana tersebut mati dalam menjalani hukuman-hukuman yang sebelumnya maka hapuslah hukuman-hukuman yang selanjutnya. Oleh karena itu Imam Syafi'i meletakkan hukuman mati paling belakang karena dia tidak memakai penyerapan biasa (al-jabb).

Sebagian ulama Syafi'iyah nampaknya memakai teori penyerapan akan tetapi sebenarnya mereka memakai teori saling melengkapi. Mereka mengatakan bahwa apabila seseorang melakukan pencurian biasa, kemudian mengganggu keamanan dengan membunuh, maka dia tidak dipotong tangannya, melainkan dijatuhi hukuman mati karena gangguan keamanan. Hal ini berarti memakai teori saling melengkapi dalam hukuman, sebab kedua perbuatan tersebut adalah sejenis dan penjatuhan hukuman pada keduanya juga bertujuan sama, sehingga gangguan keamanan disebut pencurian besar, sedangkan pencurian biasa disebut pencurian kecil. ${ }^{24}$

3. Teori Campuran (al-Mukhtalath)

Teori percampuran ini dimaksudkan untuk mengatasi kelemahankelemahan dari dua metode sebelumnya yaitu teori al-jabb dan teori altadâkhul, yaitu dengan cara menggabungkan keduanya dan mencari jalan tengahnya. Dalam teori campuran ini langkah yang dilakukan adalah dengan membatasi kemutlakan dari dua teori sebelumnya. Penggabungan hukuman boleh dilakukan namun tidak boleh melampaui batas tertentu. Tujuan dari pada pemberian batas akhir ini bagi hukuman ialah mencegah adanya hukuman yang berlebihan.

\section{Pencurian Perspektif Fikih Jinâyah}

Sariqah adalah bentuk masdar dari kata sariqa yasriqu sarqan dan secara etimologis akhazha mâlahu khufyatan wa hîlatan yaitu mengambil harta milik seseorang secara sembunyi-sembunyi dan dengan tipu daya. ${ }^{25}$ Sedangkan secara terminologis, definisi sariqah adalah mengambil sejumlah harta senilai sepuluh dirham yang masih berlaku, disimpan di tempat penyimpanannya dan dilakukan oleh seorang mukallaf secara sembunyi-sembunyi serta tidak terdapat unsur syubhat, sehingga kalau

\footnotetext{
${ }^{24}$ Ahmad Hanafi, Asas-asas Hukum Pidana Islam..., 334.

${ }^{25}$ Ahmad Warson Munawwir, Kamus Al-Munawwir Arab-Indonesia Terlengkap, (Surabaya: Pustaka Progressif, 1997), 628.
} 
barang itu kurang dari sepuluh dirham yang masih berlaku maka tidak dapat dikategorikan sebagai pencurian yang pelakunya diancam dengan dengan hukuman potong tangan. ${ }^{26}$

Menurut Achmad Wardi Muslich, pencurian menurut syara' adalah pengambilan oleh seorang mukallaf yang baligh dan berakal terhadap harta milik orang lain dengan cara diam-diam, apabila barang tersebut mencapai nishab atau batas minimal, dari tempat simpanannya tanpa ada syubhat dalam barang yang diambil tersebut. ${ }^{27}$

Pencurian apabila ditinjau dari segi hukumannya dibagi menjadi dua macam yaitu:

a. Pencurian dengan hukuman had

b. Pencurian dengan hukuman ta'zîr. Pencurian dengan hukuman had dibagi menjadi dua, yaitu:

1) Pencurian ringan

2) Pencurian berat

Pencurian ringan menurut rumusan yang dikemukakan oleh Abdul Qadir Audah adalah pencurian ringan adalah mengambil harta milik orang lain dengan cara diam-diam yaitu dengan jalan sembunyi-sembunyi.

Sedangkan pengertian pencurian berat adalah Pencurian berat adalah mengambil harta milik orang lain dengan cara kekerasan. ${ }^{28}$ Pencurian jenis ini disebut sebagai perampokan.

Menurut Abdul Qadir Audah menjelaskan bahwa ada perbedaan antara pencurian ringan dan pencurian berat. Pencurian ringan ialah pengambilan harta kekayaan yang tidak disadari oleh korban dan dilakukan tanpa izin. Pencurian kecil ini harus memnuhi dua unsur tersebut secara bersamaan. Kalau salah satu dari kedua unsur tersebut tidak ada, maka tidak dapat disebut sebagai pencurian kecil. Jika ada seseorang yang mencuri harta benda dari sebuah rumah dan disaksikan si pemilik dan si pencuri tidak menggunakan kekerasan, maka kasus seperti itu tidak termasuk pencurian kecil, tetapi penjarahan, baik penjarahan, penjambretan maupun perampasan semuanya termasuk ke dalam ruang lingkup pencurian. Namun demikian, jarimah itu tidak dikenakan hukuman had (tetapi hukuman ta'zîr). ${ }^{29}$ Hukuman potong tangan tidak diberlakukan pada pelaku penjarahan, penjambretan dan perampasan

\footnotetext{
${ }^{26}$ Nurul Irfan dan Masyarofah, Fikih Jinayah, (Jakarta: Amzah, 2013), 99.

${ }^{27}$ Ahmad Wardi Muslich, Pengantar dan Asas Hukum Pidana Islam..., 81-82.

${ }^{28}$ Abdul Qadir Awdah, At-Tasyrî” al-Jinâ'iy al-Islâmiy..., 514.

${ }^{29}$ Nurul Irfan dan Masyarofah, Fikih Jinayah..., 101.
} 
karena tidak terpenuhinya unsur-unsur pencurian berdasarkan hadis berikut di bawah ini:

Telah mengabarkan kepada kami Abu 'Ashim dari Ibnu Juraij ia berkata;

Abu Az-Zubair berkata; Jabir berkata; Rasulullah saw bersabda: "Orang yang merampas dan yang menggelapkan harta serta orang yang berkhianat tidak dipotong tangannya". (H.R. Darimi) ${ }^{30}$

Sedangkan pencurian berat adalah pencurian yang dilakukan dengan sepengetahuan korban, tetapi ia tidak mengizinkan hal itu terjadi sehingga terjadi kekerasan. Jika di dalamnya tidak terdapat unsur kekerasan maka disebut dengan penjarhan, penjambretan atau perampasan; di mana unsur kerelaan harta si pemilik tidak terpenuhi. ${ }^{31}$

Pencurian dalam KUHP diatur dalam buku kedua Bab XXII pasal 362 sampai pasal 367 tentang kejahatan. Dalam bab tersebut dijelaskan bahwa pencurian secara umum adalah mengambil suatu barang yang sama sekali atau sebagian termasuk kepunyaan orang lain tanpa seizin dari pemiliknya dengan maksud akan memiliki barang itu secara melawan hukum. ${ }^{32}$ Adapun dasar hukum pencurian dalam al-Qur'an terdapat dalam surat al-Mâidah ayat 38:

Laki-laki yang mencuri dan perempuan yang mencuri potonglah tangan keduanya sebagai pembalasan bagi apa yang mereka kerjakan dan sebagai siksaan dari Allah. Dan Allah Maha Perkasa lagi Maha Bijaksana. ${ }^{33}$

Adapun dasar hukum pencurian dalam hadis sebagai berikut:

Aisyah r.a berkata: Nabi Muhammad saw bersabda belom akan dipotong tangan pencuri dalam pencurian seperempat dinar atau lebih. ${ }^{34}$

Dalam penjelasan selanjutnya, seperempat dinar jika dikonversi ke rupiah mendapatkan nilai sebesar Rp. 425.000,-. Hal tersebut mengacu terhadap perhitungan berikut: 1 Dinar $=4.25$ gram emas. 1 gram emas $=$ Rp. 400.000. Jadi, Rp. 400.000x4.25 = Rp. 1.700.000. berarti 1/4 Dinar adalah Rp. $1.700 .000: 4$ = Rp. $425.000 .{ }^{35}$

Imam Syafi'i berpendapat bahwa hadis Rasulullah di atas menunjukkan atas orang yang dikehendaki oleh Allah swt untuk dipotong

\footnotetext{
${ }^{30}$ Abdullah bin Abdurrahman Ad-Darimiy, Sunan Ad-Dârimiy, Juz 2, (Beirut: Dar al Fikr, t.t), 175.

${ }^{31}$ Nurul Irfan dan Masyarofah, Fikih Jinayah..., 102.

${ }^{32}$ Moeljatno, Kitab Undang-undang Hukum Pidana, (Jakarta: Bumi Aksara, 2011), 376.

${ }^{33}$ Depag RI, Al-Qur'an Terjemah Indonesia, (Jakarta: Sari Agung, 2002), 204.

${ }^{34}$ Ibnu Mas'ud dan Zainal Abidin, Fiqih Madzhab Syafi'i: Buku 2 Muamalat, Munakahat, Jinayat, (Bandung, CV Pustaka Setia, 2000), 565.

35 Izzahengineering, "Bagaimana Teknik Konversi Rupiah Ke Dinar atau Dirham", http://izzahengineering.wordpress.com/2008/11/12/bagaimana-teknik-konversi-rupiah-ke-dinardirham/ diakses pada 02 Juli 2014.
} 
tangannya dari para pencuri yang telah baligh. Hadis tersebut juga memberikan pemahaman bahwa pencuri yang wajib dipotong tangannya adalah orang yang curiannya mencapai seperempat dinar ke atas. ${ }^{36}$

\section{Pembunuhan dalam Perspektif Fikih Jinâyah}

Pembunuhan berencana merupakan suatu tindakan merampas kehidupan manusia lain atau membunuh dengan telah merencanakan waktu dan metode dengan tujuan memastikan keberhasilan pembunuh dan menghindari kemungkinan tertangkap. Pembunuhan jenis ini masuk kategori pembunuhan yang serius yang memungkinkan pelaku untuk dihukum mati. Di zaman sekarang nampaknya pembunuhan berencana telah menjadi sesuatu yang cukub akrab di telinga kita, televisi, radio maupun media cetak seakan menjadi mediator utama tersebarnya kejahatan ini.

Seperti halnya di atas, Islam pun memiliki definisi mengenai pembunuhan berencana. Pembunuhan berencana atau yang biasa disebut juga sebagai pembunuhan sengaja merupakan pembunuhan atau penganiyaan yang disertai niat atau maksud menghilangkan nyawa korban. ${ }^{37}$ Pembunuhan diartikan oleh para ulama sebagai suatu perbuatan manusia yang menyebabkan hilangnya nyawa. ${ }^{38}$

Ayat-ayat al-Qur'an yang berkaitan dengan tindak pidana pembunuhan antara lain dalam surat al-Baqarah ayat 178 :

Hai orang-orang yang beriman, diwajibkan atas kamu qishâsh berkenaan dengan orang-orang yang dibunuh; orang merdeka dengan orang merdeka, hamba dengan hamba, dan wanita dengan wanita. Maka Barangsiapa yang mendapat suatu pema'afan dari saudaranya, hendaklah (yang mema'afkan) mengikuti dengan cara yang baik, dan hendaklah (yang diberi ma'af) membayar (diyat) kepada yang memberi ma'af dengan cara yang baik (pula). yang demikian itu adalah suatu keringanan dari Tuhan kamu dan suatu rahmat. Barangsiapa yang melampaui batas sesudah itu, Maka baginya siksa yang sangat pedih. ${ }^{39}$

Jarîmah pembunuhan juga dijelaskan di dalam al-Qur'an surat alMâidah ayat 45:

\footnotetext{
${ }^{36}$ Ismail Yakub, Terjemahan Al-Umm "Kitab Induk", jilid ke-9, (Semarang: t.p, 1986), 78.

${ }^{37}$ Jaih Mubarak dan Enceng, Kaidah Fikih Jinayah, (Bandung: Bani Quarisy, 2004), 10.

${ }^{38}$ Topo Santoso, Membumikan Hukum Pidana Islam; Pengangkatan Syariat dalam Wacana dan Agenda, (Jakarta: Gema Insani, 2003), 37.

${ }^{39}$ Depag RI, Al-Qur'an dan Terjemahnya, (Jakarta: Jamunu, 1965), 43.
} 
Dan kami telah tetapkan terhadap mereka di dalamnya at-Taurat bahwasanya jiwa dibalas dengan jiwa, mata dengan mata, hidung dengan hidung, telinga dengan telinga, gigi dengan gigi dan luka pun ada qishâsh nya. Barangsiapa yang melepaskan hak qishâshnya maka melepaskan hak itu menjadi penebus dosa baginya. Barang siapa tidak memutuskan perkara meurut apa yang diturunkan Allah, maka mereka itu adalah orangorang yang zalim. ${ }^{40}$

Hal tersebut juga diterangkan dalam al-Qur'an surat al-An'âm ayat 151.

..Dan janganlah kamu membunuh jiwa yang diharamkan Allah melainkan dengan sebab sesuatu yang benar, demikian itu yang diperintahkan kepadamu supaya kamu memahami(nya). ${ }^{41}$

Jarîmah pembunuhan juga dijelaskan di surat al-Isrâ' ayat 33:

Dan janganlah kamu membuuh jiwa yang diharamkan Allah (membunuhnya), melainkan dengan suatu alasan yang benar. Dan barang siapa yang dibunu secara zalim maka sesungguhnya kami telah memberi kekuasaan kepada ahli warisnya, tetapi janganlah ahli waris itu melampui batas dalam membunuh. Sesungguhnya dia adalah orang yang mendapat pertolongan. ${ }^{42}$

Berdasarkan ayat-ayat al-Qur'an yang dijadikan dasar hukum di atas, maka dirumuskan garis hukum sebagai berikut:

a. Allah swt mewajibkan kepada orang-orang yang beriman qishâsh berkenaan dengan orang-orang yang dibunuh, yaitu orang merdeka dengan orang merdeka, hamba dengan hamba dan wanita dengan wanita.

b. Barangsiapa yang mendapat suatu pemaafan dari saudaranya, yang memaafkan mengikuti dengan cara yang baik, dan hendaklah yang diberi maaf membayar diyat kepada yang memberi maaf dengan cara yang baik pula.

c. Tidak layak bagi orang mukmin membunuh orang mukmin lain kecuali dengan tidak sengaja.

d. Barang siapa yang membunuh orang mukmin dengan sengaja maka balasannya adalah masuk neraka jahannam dan kekal di dalamnya. ${ }^{43}$ Adapun jarîmah pembunuhan dibagi menjadi tiga macam: ${ }^{44}$

\footnotetext{
${ }^{40} \mathrm{lbid}, .167$.

${ }^{41} \mathrm{lbid} ., 214$

$42 \mathrm{lbid}, 429$.

${ }^{43}$ Zainuddin Ali, Hukum Pidana Islam, (Jakarta: Sinar Grafika, 2012), $28-29$.

${ }^{44}$ A. Djazuli, Fikih Jinayah, (Jakarta: Raja Grafindo Persada, 1997), 123.
} 
a. Pembunuhan sengaja yaitu perbuatan yang dilakukan seseorang dengan sengaja untuk membunuh orang lain, secara kejam dengan alat yang biasa dipakai untuk membunuh. Seperti pisau, golok, bedil, parang dan senjata tajam lain atau dengan benda lain yang sangat mematikan seperti racun dan lain sebagainya. Perbuatan ini dikenal dengan sebutan qatl al-'amd. Adapun unsur-unsur dari pembunuhan sengaja adalah sebagai berikut:

1) Korban adalah orang yang hidup.

2) Perbuatan si pelaku yang mengakibatkan kematian korban.

3) Ada niat bagi si pelaku untuk menghilangkan nyawa korban. ${ }^{45}$

b. Pembunuhan tidak sengaja yaitu perbuatan yang disengaja terhadap diri seseorang yang dengan alat yang tidak biasa digunakan untuk membunuh, seperti sapu, sapu tangan, pensil dan lain sebagainya. Perbuatan ini sering disebut dengan qatl syibh al-'amd artinya diserupakan dengan pembunuhan yang disengaja. Adapun unsurunsur dari pembunuhan semi sengaja adalah sebagai berikut:

1) Pelaku melakukan suatu perbuatan yang mengakibatkan kematian.

2) Ada maksud penganiayaan atau permusuhan.

3) Ada hubungan sebab akibat antara perbuatan pelaku dengan kematian korban. ${ }^{46}$

c. Pembunuhan karena kesalahan yang biasa dikenal dengan qatl alkhata' artinya perbuatan yang tidak ditujukan kepada seseorang. Seperti seseorang yang hendak menembak seekor harimau, tetapi mengenai seorang manusia dan mengakibatkan hilangnya nyawa orang tersebut. Adapun unsur-unsur pembunuhan kesalahan sebagai berikut:

1) Adanya perbuatan yang menyebabkan kematian.

2) Terjadinya perbuatan itu karena kesalahan.

3) Adanya hubungan sebab akibat antara perbuatan kesalahan dengan kematian korban. ${ }^{47}$

Analisis Fikih Jinâyah terhadap Perbarengan Tindak Pidana Pembunuhan Berencana dan Pencurian dengan Kekerasan

Berdasarkan prinsip fikih jinâyah bahwa perbuatan tindak pidana yang dilakukan oleh seseorang harus disesuaikan dengan keadilan menurut petunjuk Allah swt. Oleh karena itu, dalam menentukan hukum, yang

\footnotetext{
${ }^{45}$ Ibid., 128.

${ }^{46} \mathrm{lbid} ., 132$.

${ }^{47}$ lbid., 134
} 
pertama harus didasarkan kepada keimanan wahyu Allah swt yaitu alQur'an dan kedua didasarkan kepada akal sehat manusia untuk mendapatkan kemaslahatan bersama di dunia maupun di akhirat.

Menurut fikih jinâyah, hukuman merupakan alat untuk menegakkan kepentingan masyarakat. Oleh karena itu, besarnya hukuman harus disesuaikan dengan kebutuhan masyarakat yakni tidak boleh melebihi apa yang diperlukan untuk melindungi kepentingan masyarakat.

Pembunuhan berencana dan pencurian dengan kekerasan merupakan delik yang bukan hanya meresahkan individu saja tetapi juga meresahkan masyarakat karena hal tersebut dipandang sebagai tindak kejahatan yang melanggar norma hukum dan agama. Maka dari itu sudah selayaknyalah jika pelaku tindak pidana (concurusus) perbarengan tindak pidana antara delik pembunuhan berencana dan pencurian dengan kekerasan mendapatkan hukuman yang sangat berat.

Dalam kaidah fikih jinâyah, khususnya tentang ta'addud al-jarâ'im atau gabungan tindak pidana terdapat dua macam gabungan tindak pidana, yaitu gabungan anggapan (concursus idealis) yaitu adanya dua gabungan jarîmah itu karena halnya bersifat anggapan, sedangkan pelakunya hanya berbuat jarîmah ${ }^{48}$ dan gabungan nyata (concursus realis) yaitu seseorang melakukan perbuatan jarîmah ganda secara jelas, baik berkenaan dengan jarîmah sejenis maupun berbeda. ${ }^{49}$ Misalnya kasus pelaku pembunuhan dan pencurian dengan kekerasan terhadap beberapa korban yang mengakibatkan hilangnya nyawa terhadap korban yang satu dan luka berat terhadap korban lainnya. Dalam fikih jinâyah, pelaku diberikan satu hukuman saja yaitu hukuman terberat dari salah satu kedua perbuatan tindak pidana tersebut. Alasan penjatuhan satu hukuman saja ialah bahwa pada dasarnya suatu hukuman dijatuhkan dengan masksudkan memberikan pengajaran (ta'dîb) dan pencegahan terhadap orang lain (jazra').

Seseorang yang melakukan tindak pidana pembunuhan (qishâsh), maka hukumannya adalah juga dengan dibunuh. Hal ini sesuai dengan firman Allah swt di dalam al-Qur'an surat al-Mâidah ayat 45:

Dan kami telah tetapkan terhadap mereka di dalamnya at-Taurat bahwasanya jiwa dibalas dengan jiwa, mata dengan mata, hidung dengan hidung, telinga dengan telinga, gigi dengan gigi dan luka pun ada qishâsh

\footnotetext{
${ }^{48}$ Makhrus Munajat, Dekonstruksi Hukum Pidana Islam, (Jogjakarta: Logung Pustaka, 2004), 46. ${ }^{49}$ lbid., 47.
} 
nya. Barangsiapa yang melepaskan hak qishâsh nya maka melepaskan hak itu menjadi penebus dosa baginya. Barang siapa tidak memutuskan perkara meurut apa yang diturunkan Allah, maka mereka itu adalah orangorang yang zalim. ${ }^{50}$

Sementara itu, setiap orang yang melakukan tindak pidana pencurian, maka hukumannya adalah potong tangan. Hal ini sesuai dengan firman Allah swt dalam surat al-Maîdah ayat 38:

Laki-laki yang mencuri dan perempuan yang mencuri potonglah tangan keduanya sebagai pembalasan bagi apa yang mereka kerjakan dan sebagai siksaan dari Allah. Dan Allah Maha Perkasa lagi Maha Bijaksana. ${ }^{51}$

Namun, tidak semua pencurian yang diberikan hukuman potong tangan. Karena hukuman potong tangan hanya diberikan kepada pelaku pencurian yang barang curiannya mencapai seperempat dinar, yang jika dikalkulasi ke rupiah adalah setara dengan Rp. 425.000,- (empat ratus dua puluh lima ribu rupiah). ${ }^{52} \mathrm{Hal}$ tersebut sesuai dengan hadis Nabi berikut ini:

Aisyah ra berkata: Nabi Muhammad saw bersabda belum akan dipotong tangan pencuri dalam pencurian seperempat dinar atau lebih. ${ }^{53}$

Jika dalam kasus perbarengan tindak pidana (concursus) atau gabungan hukuman untuk tindak pidana pembunuhan, unsur-unsurnya sudah terpenuhi semua, maka hukuman atau balasan dari tindakan tersebut adalah hukuman mati. Sedangkan untuk tindak pidana pencurian, unsur-unsurnya juga terpenuhi karena barang yang diambil/dirampas mencapai seperempat dinar atau setara dengan Rp. 425.000,- (empat ratus dua puluh lima ribu rupiah), maka balasan hukuman dari tindak pidana pencurian tersebut harus dipotong tangan.

Menurut penulis, jika hal ini ditinjau dengan fikih jinâyah, maka tindak pidana pembunuhan berencana dan pencurian dengan kekerasan seharusnya mendapat hukuman mati atau qishâsh. Hal tersebut didasarkan kepada salah satu teori yang digunakan dalam memutuskan perkara gabungan tidak pidana yang di dalam kaidah fikih jinâyah dikenal dengan ta'addud al-jarâ'im atau gabungan hukuman, yaitu teori penyerapan (al-jabb). Teori al-jabb atau teori penyerapan adalah

\footnotetext{
${ }^{50}$ Depag RI, Al-Qur'an Terjemahan Indonesia, (Jakarta: Sari Agung, 2002), 207.

51 lbid, 204.

52 Izzahengineering, "Bagaimana Teknik Konversi Rupiah Ke Dinar atau Dirham", http://izzahengineering.wordpress.com/2008/11/12/bagaimana-teknik-konversi-rupiah-ke-dinardirham/ diakses pada 02 Juli 2014.

${ }^{53}$ Ibnu Mas'ud dan Zainal Abidin, Fiqih Madzhab Syafi'i: Buku 2 Muamalat, Munakahat, Jinayat, 565.
} 
penjatuhan satu hukuman terhadap pelaku tindak pidana ganda dengan cara hukuman yang lebih kecil diserap oleh hukuman yang lebih besar, dalam hal ini adalah hukuman mati.

Oleh karena itu, pelaku tindak pidana yang melakukan pembunuhan berencana dengan unsur-unsurnya yang telah terpenuhi dan tindak pidana pencurian dengan kekerasan yang unsur-unsurnya juga terpenuhi secara keseluruhan, maka hukuman yang dijatuhkan terhadap pelaku tersebut adalah hukuman mati. Karena hukuman yang merupakan balasan dari pidana pencurian diserap oleh hukuman yang merupakan balasan dari tindak pidana pembunuhan berencana.

\section{Simpulan}

Dalam hukum pidana Indonesia, pembunuhan termasuk klasifikasi kejahatan terhadap nyawa, sedangkan pencurian masuk ke dalam kategori kejahatan terhadap harta. Pembunuhan diatur mulai pasal 338 KUHP sampai pasal 350 KUHP, sedangkan pencurian diatur mulai pasal 362 KUHP sampai pasal 367 KUHP. Pembunuhan berencana diatur dalam pasal 340 KUHP jo. pasal 55 ayat (1) ke 1 dan pencurian dengan kekerasan diatur dalam pasal 365 ayat (2) ke 2 Kitab Undang-Undang hukum Pidana.

Adapun pandangan fiqh jinâyah terhadap perbarengan tindak pidana (concursus) pembunuhan berencana dan pencurian dengan kekerasan seharusnya mendapat hukuman mati atau qishâsh. Hal tersebut didasarkan kepada salah satu teori yang digunakan dalam memutuskan perkara gabungan tidak pidana yang di dalam kaidah fiqh jinâyah dikenal dengan ta'addud al-jarâ'im atau gabungan hukuman, yaitu teori penyerapan (al-jabb). Teori al-jabb atau teori penyerapan adalah penjatuhan satu hukuman terhadap pelaku tindak pidana ganda dengan cara hukuman yang lebih kecil diserap oleh hukuman yang lebih besar, dalam hal ini adalah hukuman mati.

\section{Daftar Rujukan}

Ali, Zainuddin. Hukum Pidana Islam. Jakarta: Sinar Grafika, 2012. Awdah, Abdul Qadir. Al-Tasyrî̀ al-Jinầiy al-Islâmiy. Beirut: Dar al-Kitab al-Arabi, t.t.

Chazawi, Adami. Pelajaran Hukum Pidana 2. Jakarta: Rajawali Pers, 2002. 
Departemen Agama RI. Al-Qur'an dan Terjemahnya. Jakarta: Jamunu, 1965.

Djazuli, A. Fikih Jinâyah. Jakarta: Raja Grafindo Persada, 1997.

Al-Dârimiy, Abdullah ibn Abdurrahman. Sunan ad-Dârimiy. Beirut: Dar al Fikr, t.t.

Hanafi, Ahmad. Asas-asas Hukum Pidana Islam. Jakarta: Bulan Bintang, 1990.

Al-Tirmidziy. Sunan al-Tirmidziy. Beirut: Dar al-Fikri, 2005.

Irfan, Nurul. dan Masyarofah. Fikih Jinâyah. Jakarta: Amzah, 2013.

Izzahengineering. "Bagaimana Teknik Konversi Rupiah Ke Dinar atau Dirham", http://izzahengineering.wordpress.com/2008/11/12/bagaimanateknik-konversi-rupiah-ke-dinar-dirham/ diakses pada 02 Juli 2014.

Kansil, C.S.T. dan Christine S.T. Kansil. Latihan Ujian Hukum Pidana. Jakarta: Sinar Grafika, 1994.

Mas'ud, Ibnu. dan Zainal Abidin. Fiqih Madzhab Syafi'i: Buku 2 Muamalat, Munakahat, Jinayat. Bandung, CV Pustaka Setia, 2000.

Moeljatno. Kitab Undang-undang Hukum Pidana. Jakarta: Bumi Aksara, 2011.

Mubarak, Jaih. dan Enceng. Kaidah Fikih Jinâyah. Bandung: Bani Quarisy, 2004.

Munajat, Makhrus. Dekonstruksi Hukum Pidana Islam. Jogjakarta: Logung Pustaka, 2004.

Teras, 2009.

Nasihuddin. "Gabungan Melakukan Tindak Pidana (Concursus) Menurut KUHP”, http://www.nasihudin.com/artikel/gabunganmelakukan-tindak-pidana-concursus-menurut-kuhp/28/.html, diakses pada tanggal 24 Juni 2014.

Prasetyo, Teguh. Hukum Pidana. Jakarta: Rajawali Pers, 2011.

Sakidjo, Aruan. dan Bambang Pornomo. Hukum Pidana Dasar Aturan Umum, Hukum Pidana Kodifikasi. Jakarta: Ghalia Indonesia, 1990.

Santoso, Topo. Membumikan Hukum Pidana Islam; Pengangkatan Syariat dalam Wacana dan Agenda. Jakarta: Gema Insani, 2003. 
Soesilo, R. Kitab Undang-undang Hukum Pidana Serta Komentarkomentarnya Pasal Demi Pasal. Bogor: Politeia, 1988.

Software Kitab 9 Imam Hadith, Kitab Pelanggaran, Bab (Imam Malik) berkata: "Karena itu Pihak yang Tertuduh Merasa Khawatir Jika Permasalahannya Terbongkar Sehingga Diberikan Bukti Kepadanya, No. 1306.

Muslich, Ahmad Wardi. Pengantar dan Asas Hukum Pidana Islam. Jakarta: Sinar Grafika, 2004.

Munawwir, Ahmad Warson. Kamus Al-Munawwir Arab-Indonesia Terlengkap. Surabaya: Pustaka Progressif, 1997.

Yakub, Ismail. Terjemahan Al-Umm "Kitab Induk", Jilid ke-9. Semarang: t.p, 1986. 